\title{
Fish fauna of the Fitzroy River in the Kimberley region of Western Australia - including the Bunuba, Gooniyandi, Ngarinyin, Nyikina and Walmajarri Aboriginal names
}

\author{
David L. Morgan', Mark G. Allen', Patsy Bedford ${ }^{2}$ and Mark Horstman ${ }^{3}$ \\ ${ }^{1}$ Centre for Fish \& Fisheries Research, School of Biological Sciences and Biotechnology, \\ Murdoch Unversity, Murdoch, Western Australia 6150 \\ Kimberley Language Resource Centre, PO Box 86, Fitzroy Crossing, Western Australia 6765 \\ Kimberley Land Council, PO Box 2145, Broome Western Australia 6725
}

\begin{abstract}
This project surveyed the fish fauna of the Fitzroy River, one of Australia's largest river systems that remains unregulated, located in the Kimberley region of Western Australia. A total of 37 fish species were recorded in the 70 sites sampled. Twenty-three of these species are freshwater fishes (i.e. they complete their life-cycle in freshwater), the remainder being of estuarine or marine origin that may spend part of their life-cycle in freshwater. The number of freshwater species in the Fitzroy River is high by Australian standards. Three of the freshwater fish species recorded are currently undescribed, and two have no formal common or scientific names, but do have Aboriginal names. Where possible, the English (common), scientific and Aboriginal names for the different species of the river are given. This includes the Aboriginal names of the fish for the following five languages (Bunuba, Gooniyandi, Ngarinyin, Nyikina and Walmajarri) of the Fitzroy River Valley. The fish fauna of the river was shown to be significantly different between each of the lower, middle and upper reaches of the main channel. Furthermore, the smaller tributaries and the upper gorge country sites were significantly different to those in the main channel, while the major billabongs of the river had fish assemblages significantly different to all sites with the exception of the middle reaches of the river. The previously known ranges of many species were extended. The implications of damming the Fitzroy River are discussed.
\end{abstract}

\section{INTRODUCTION}

The Kimberley region of Western Australia is home to a unique assemblage of freshwater fishes that is exposed to high summer rainfall and a dry winter period. Much of the landscape is rugged, with vehicular access seasonally limited. This, together with the isolation of the region, has resulted in only limited distributional fish faunal surveys being conducted. Fish surveys have often revealed species that are new to science, or have greatly extended the ranges of the species captured. The most notable surveys of the Kimberley include those on the Gibb River Road to the Drysdale River (by Rosen, Nelson and Butler in 1969 for the American Museum of Natural History), the Ord River area (McKay, 1971), the Prince Regent River (Allen, 1975), Drysdale River (Hutchins, 1977), Mitchell, King Edward and Lawley rivers (Hutchins, 1981), Hutchins and Chapman (Hutchins, unpublished data) surveyed the Gibb River Road in 1975 (see Hutchins, 1981), Allen and Allen sampled stream crossings on the Gibb River and Kulumburu roads (Allen and Allen, unpublished data) and Allen and Leggett (1990) sampled numerous sites on the Isdell, Mitchell, King Edward, Drysdale and Ord rivers. Surprisingly, the largest river of the Kimberley, the Fitzroy, which drains over one-third of the region, has only been surveyed in a few easily accessed locations (see Allen and Leggett, 1990).

The Fitzroy River is large by Western Australian standards, draining almost $90000 \mathrm{~km}^{2}$, and is largely uncleared, with its water non-saline throughout most of its length (Anon, 1993; Storey, 1998). The Fitzroy River is one of the largest unregulated rivers in Australia, but has recently been identified as having the potential to supply quality water to not only the Kimberley, but also other parts of Australia (Anon, 1993, Storey, 1998). A number of dam sites have been recognised including Dimond Gorge and Margaret Gorge (Anon, 1993). While providing water for agriculture and domestic uses, the proposed dams have been seen by some as a means of controlling natural flooding in the Fitzroy River floodplain (Anon, 1993).

The Fitzroy River catchment experiences a semi- 


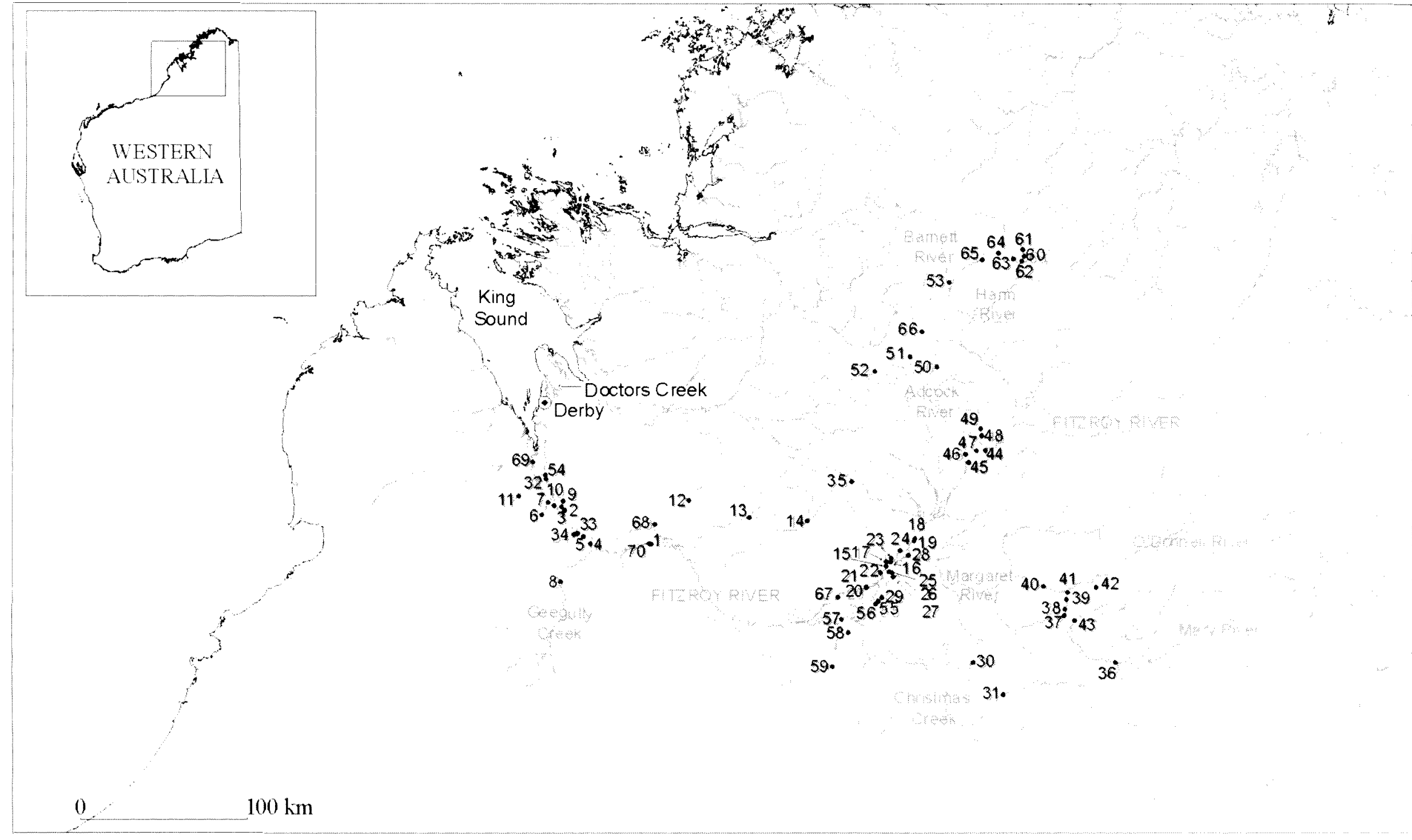

Figure 1 The sites sampled for fish in the Fitzroy River, Western Australia. 
arid to arid monsoonal climate receiving most ( $90 \%$ ) of its rainfall between November and March (i.e. the wet season) (Goh, 1998; Ruprecht and Rodgers, 1998). Upstream of Fitzroy Crossing the river catchment covers approximately $45000 \mathrm{~km}^{2}$ and divides into two main tributaries, the Fitzroy and Margaret rivers, which also encompass the high relief reaches of the river (Ruprecht and Rodgers, 1998). The main tributaries of the upper Fitzroy include the Hann, Adcock, Louisa and Little Fitzroy rivers, while those of the Margaret include the Mary, Leopold, O'Donnell, Gidden, Little Gold and Laura rivers (see Figure 1) (Ruprecht and Rodgers, 1998). Downstream of Fitzroy Crossing lies the river floodplain, which extends some $300 \mathrm{~km}$ to the coast. and includes the tributaries of Christmas, $\mathrm{Mt}$ Hardman, Mt Wynne and Geegully creeks. The mean annual streamflow of $6150 \mathrm{GL} /$ vear (since the 1950s) at Fitzroy Crossing is the highest of any river system recorded in Western Australia (Ruprecht and Rodgers, 1998). While flows peak during the wet season, in the dry season flow may cease with the river becoming a series of disconnected pools and billabongs. Turbidity is also seasonally affected, with highest turbidities coinciding with peak flows during the wet season (Ruprecht and Rodgers, 1998).

The present study represents part of an ongoing collaboration between Murdoch University, the Kimberley Land Council, the Kimberley Language Resource Centre and the local community, including the traditional owners and station owners, of the Fitzroy River catchment. The importance of the Fitzroy River to the Aboriginal people of the region is highlighted in this report, and where possible, the Bunuba, Gooniyandi, Ngarinyin, Nyikina, Walmajarri, English (common) and scientific names are given for each fish species recorded from the Fitzroy River system. A further aim of this project was to address the notable lack of distributional data for the fish fauna of the Fitzroy River, while also examining the fish faunal associations within the various habitat types of the river. Furthermore, the importance of the river to the people of the Kimberley region and the conservation issues affecting fish distributions are discussed.

\section{MATERIALS AND METHODS}

\section{Sampling for fish}

During four two-week surveys, between April 2001 and November 2002, and two short field trips in March and December 2002, a total of 70 sites were sampled for fish throughout the main channel of the Fitzroy River, its tributaries and associated wetlands/billabongs (see Appendix 1). Many of the sites are of Aboriginal significance and located within areas covered by native title applications, and the survey team was guided by traditional owners and their knowledge. With the exception of one site (Telegraph Pool), all sites sampled in the river were above the limit of tidal influence. Additionally, species recorded in the estuary and Doctor's Creek, near the mouth of the Fitzroy River (see Figure 1), during opportunistic sampling, are included in the results.

Sampling equipment included a variety of seine nets $11 \mathrm{~m}$ (1 mm mesh), 5, 10 and $15 \mathrm{~m}$ (all $3 \mathrm{~mm}$ mesh), $26 \mathrm{~m}$ (6 and $3 \mathrm{~mm}$ mesh) and a $60 \mathrm{~m}$ (10 and $5 \mathrm{~mm}$ mesh)], gill nets (25 to $125 \mathrm{~mm}$ stretched mesh sizes), cast nets, masks and snorkels and hooks and lines.

Active participants included the Centre for Fish and Fisheries Research at Murdoch University, the Land + Sea Management Unit at the Kimberley Land Council (KLC), the Fitzroy Crossing Kimberley Language Resource Centre (KLRC), station owners and tenants, and community members from Broome, Derby and Fitzroy Crossing and their surrounds, including the Bunuba, Gooniyandi, Ngarinyin, Nyikina and Walmajarri traditional owners

\section{Environmental variables}

The conductivity, temperature and $\mathrm{pH}$ of water taken just below the surface were recorded at each sample site.

\section{Species identification and maps}

Each species captured was photographed with some specimens preserved for identification and for the collections of the Western Australian Museum. The majority of fish were released alive after capture. The phylogenetic order of the families (and the subsequent species list) follows Nelson (1994). Longitude and latitude were recorded at each site using a Global Positioning System (GPS). The sample sites map was created using the above GPS data and MapInfo (MapInfo Corporation, 1998).

\section{Classification of sample sites and Analysis of Similarity (ANOSIM)}

In order to test the hypothesis that fish faunal composition would vary between the lower (sites $1-6,9,32-34,54,68,70)$, middle $(15-16,18-20,28$, $57,67)$ and upper $(36-41,44-45)$ reaches of the main channel/major tributaries of the river and also the smaller tributaries (sites 8, 11-14, 17, 22-25, 27, 30$31,35,43,46-52,55-56,58-59)$, the large lentic billabongs (sites $7,10,21,26,29$ ) and the upper gorge country e.g. upper Hann River (sites 42, 53, 60-66) (see Figure 1), the sample sites were a priori allocated to one of these broad habitat categories and their fish community structures compared using one-way analysis of similarity (ANOSIM) in PRIMER (Clarke and Gorley, 2001). 
In order to test for differences in community structure, a presence-absence data set of the different species captured in the 70 sites sampled in the Fitzroy River catchment was used to construct a similarity matrix employing the Bray-Curtis similarity coefficient in the PRIMER package (Clarke and Gorley, 2001). The presence-absence data were considered to be more appropriate than abundance data for a number of reasons: 1 . Water levels, and thus sampling efficiency, varied greatly between the sampling periods, i.e. late wet and late dry; 2 . The level of sampling effort was governed by site characteristics, e.g. size and depth; 3 . The requirement of a number of capture techniques to effectively sample the variety of species in the different sites, e.g. different meshed seine nets (larger net generally equals larger mesh size), mask and snorkel only in clear waters, seine nets not as

Table 1 The sites at which the different freshwater fish species were captured in the Fitzroy River (see Figure 1 for site localities and Table 3 for common and Aboriginal names).

\begin{tabular}{l} 
Freshwater species \\
\hline Anguillidae \\
Anguilla bicolor McClelland, 1844 \\
Clupeidae \\
$\quad$ Nematalosa erebi (Günther, 1868) \\
Ariidae \\
Arius graeffei Kner and Steindachner, 1867 \\
Plotosidae \\
$\quad$ Anodontiglanis dahli Rendahl, 1922 \\
Neosilurus ater (Perugia, 1894) \\
Neosilurus hyrtlii Steindachner, 1867 \\
Neosilurus psetidospinosus Allen and Feinberg, 1998 \\
Porochilus rendahli (Whitley, 1928)
\end{tabular}

Belonidae

Strongylura krefftii (Günther, 1866)

Melanotaeniidae

Melanotaenia australis (Castelnau, 1875)

Atherinidae

Craterocephalus lentiginosus Ivantsoff, Crowley and Allen, 1987

Ambassidae

Ambassis sp. 1

Ambassis sp. 2

Apogonidae Glossamia aprion (Richardson, 1842)

Toxotidae

Toxotes sp.

Teraponidae

Amniataba percoides (Günther, 1864)

Hannia greenwayi Vari, 1978

Hephaestus jenkinsi (Whitley, 1945)

Leiopotherapon unicolor (Günther, 1859)

Eleotridae

Hypseleotris kimberleyensis Hoese and Allen, 1983

Mogurnda oligolepis Allen and Jenkins, 1999

Oxyeleotris selheimi (Macleay, 1884)

Gobiidae

Glossogobius giuris (Hamilton, 1822)
Site numbers

Total

18

$1-9,11-12,15-20,23,25-27,29-34,36-45$

$49-50,54,57-59,61-62,65-68$

49

$1,3-4,18-19,26,29,32,34,36,38-41,44-45,57,67-70$

21

$1-2,4,10,12,25,34,68$

45

$1-7,9-10,12-19,24,29-34,36,38,42-43,45,47,54,63-64 \quad 33$

$36,38,42,45,53$

$10,12,15,21,24,26,29,56$

\section{5}

8

$1,3-4,6,9,15-18,20,23,26,29,32-34,37,39-41$, $44-45,67-68$

24

$2,4-9,12-15,17-31,33,35-43,45-54,58-66,68$

$7,10,15-18,20-21,29,55,67-68$

12

$16,18-24,26-29,43,45-51,53-56,61,64-66$

$2-6,9-13,15-17,20,23,33,35,45,54,58,67-68$

22

$1-2,7,10,15-20,26,28-29,33,56,58,67-69$

$1-7,10,12,15-18,26,28-29,32-34,40,42-46,49$, $54,57,67-68$

$9,16-20,26,28-29,36,38-46,48-49,53,55$,

28

$60-61,65,67-68$

$36-37,40,42,45-46,61,66-67$

$3,16,18,25-26,28,31-32,34,38,40,42,44-46$,

$48-49,53,57,61,65-68$

$1-26,28-43,45-54,56-68$

24

65

53,65

$53,61,66$

$10,17,22,29,33,36,40,43,48-49,55$

2

11

$2-5,7-8,16,18-20,23,26-29,32-33,36-46,48$,

38 
effective as gill nets or hook and line for capturing larger species (e.g. barramundi, lesser salmon catfish and freshwater sawfish). Thus, estimates of relative abundance could not be standardised for all sites.

\section{Aboriginal names for the fish}

During and after field trips, linguists from the KLRC and KLC consulted Bunuba, Gooniyandi, Ngarinyin, Nyikina and Walmajarri language speakers from communities of the Fitzroy River valley. Where possible, traditional owners were consulted in the field using live fishes, however it was also necessary to show photographs of species that were not captured on specific field trips. Fish names were recorded, wherever possible, for each of the species captured.

\section{RESULTS}

\section{Environmental variables}

The mean pH of the sites sampled (Appendix 1, Figure 1) was 8.17 ( \pm 0.085 s.e.) and ranged from 6.8 to 10.6. With the exception of one site, all sites sampled were alkaline. The water temperatures of the sites sampled ranged from 15.1 to $33.0^{\circ} \mathrm{C}$ and had a mean of $26.8^{\circ} \mathrm{C}( \pm 0.68$ s.e. $)$. The coldest site (site 64), which was sampled in June, was in the Hann River. With the exception of the estuarine site (Telegraph Pool, site 69), which was 6 ppt ( 9 $\mathrm{mScm}^{-1}$ ), and Manguel Creek (site 11), which had a salinity if $19.4 \mathrm{ppt}$, all sites sampled were freshwater. The mean conductivity of all other sites was $0.89 \mathrm{mScm}^{-1}( \pm 0.383$ s.e. $)$.

\section{Fish species captured}

The 70 sample sites (Appendix 1, Figure 1) in the Fitzroy River yielded a total of 37 species in 31 genera from 23 families (Plates 1 and 2, Tables 1 and 2). Of these, 23 species are primarily freshwater fishes, while 14 species are considered of estuarine or marine origin but may spend part of their lifecycle in the freshwaters. For the purposes of this paper, a freshwater species is defined as one that is either restricted to freshwater, breeds in freshwater or spends the majority of their life-cycle in freshwater. Marine and estuarine species are defined as those that sometimes penetrate freshwaters, but predominantly occur and/or breed in marine or estuarine environs. An exception should be noted, that being the short-finned eel (Anguilla bicolor), which breeds in the sea, but was included in the freshwater category as it spends the majority of its life in freshwaters. The lesser salmon catfish (Arius graeffei), which is found in both fresh

Table 2 The sites at which the different marine/estuarine fish species were captured in the freshwaters of the Fitzroy River (see Figure 1 for site localities and Table 4 for common and Aboriginal names).

\begin{tabular}{lll}
\hline Marine/estuarine species & Site numbers captured at & Total \\
\hline $\begin{array}{l}\text { Carcharhinidae } \\
\text { Carcharhinus leucas (Valenciennes, 1839) }\end{array}$ & $57,69,70$
\end{tabular}

Pristidae

Pristis microdon Latham, 1794

$3-4,20,34,40-41,57,68-70$

Prist is clavata Garman, 1906

Dasyatidae

Himantura chaophraya Monkolpraist and Roberts, $1990 \quad 57,69,70$

Elopidae

Megalops cyprinoides (Broussonet, 1782) 2, $\quad 28-19,40,68$

Mugilidae

Liza subviridis (Valenciennes, 1836)

Liza alata (Steindachner, 1892)

$1-4,9,32,34,40,69$

33,68

Centropomidae

Lates calcarifer (Bloch, 1790)

Gerreidae

Gerres filamentosus Cuvier, 1829

32

Gerres subfasciatus Cuvier, 1830

Sciaenidae

Nibea squamosa Sasaki, 1992

Scatophagidae

Scatophagus argus (Linnaeus, 1766)

Selenotoca multifasciata (Richardson, 1846)

Tetraodontidae 


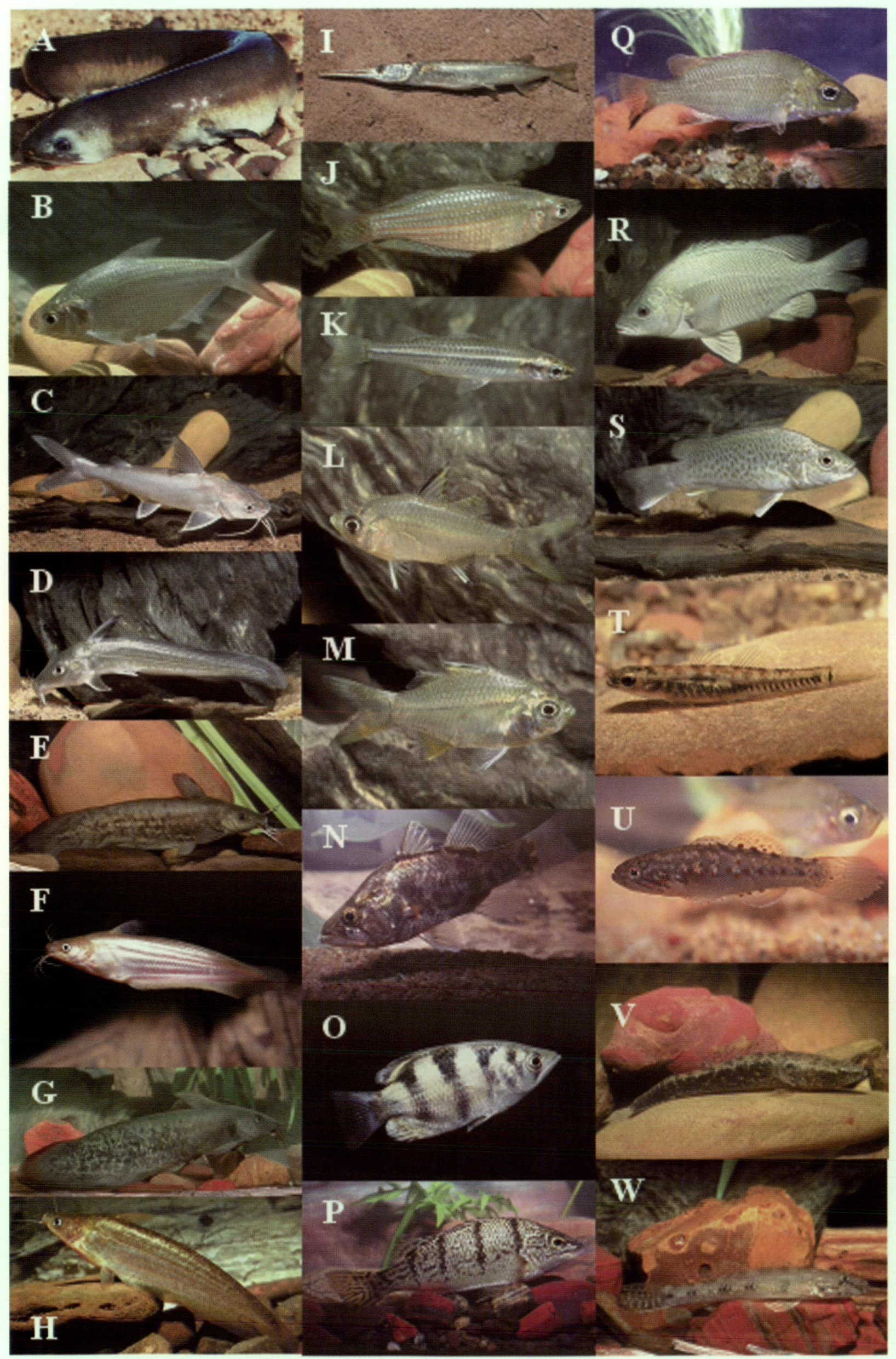


and salt waters, has also been included in the freshwater category because it breeds in freshwater.

Of the 23 species of principally freshwater fishes (Table 1, Plate 1) recorded during the survey, the families Plotosidae (eel-tailed catfishes), Terapontidae (grunters) and Eleotridae (gudgeons) were best represented with five, four and three species recorded, respectively. A number of 'ecological generalist' species were found to be widespread throughout the various broad habitat types. These included the spangled perch (Leiopotherapon unicolor) (recorded at 65 of 70 sites), western rainbowfish (Melanotaenia australis) (56 of 70 sites) and bony bream (Nematalosa erebi) (49 of 70 sites). Other species, including the black catfish (Neosilurus ater) (recorded at one site), Barnett River gudgeon (Hypseleotris kimberleyensis) (two sites), false-spotted gudgeon (Mogurnda oligolepis) (three sites), Greenway's grunter (Hannia greenwayi) (nine sites) and false-spined catfish (Neosilurus pseudospinosus) (five sites) were rare with restricted distributions in the upper reaches and headwaters of the Fitzroy River catchment. A number of species were found in moderate numbers but only in the lower and middle reaches of the main river channel, including toothless catfish (Anodontiglanis dahli), Rendahl's catfish (Porochilus rendahli) and Prince Regent hardyhead (Craterocephalus lentiginosus). The short-finned eel (Anguilla bicolor) was only recorded at one site, but this species is secretive and difficult to capture, therefore it may be more common and widespread than indicated by the results of this survey. Two glassfishes (Ambassidae) (Ambassis sp. 1 and Ambassis sp. 2) do not conform to any keys and show sufficient morphological differences to the described species to warrant species recognition. These species are currently being described by the senior author. Furthermore, one undescribed species of archerfish (Toxotidae, Toxotes sp.) was captured throughout the river and is currently being described by Dr G. Allen.

Of the 14 fish species considered to be estuarine/ marine opportunists captured in the freshwaters of the Fitzroy River (Table 2, Plate 2), most were found in small numbers only in the lower reaches of the main river channel (e.g. dwarf sawfish (Pristis clavata), mullets (Liza spp.), whipfin silverbiddy (Gerres filamentosus), roach (Gerres subfasciatus), scaly croaker (Nibea squamosa), spotted scat (Scatophagus argus), striped butterfish (Selenotoca multifasciata) and Merauke toadfish (Marilyna meraukensis)). However, barramundi (Lates calcarifer) were collected in moderate numbers throughout the main river channel and major tributaries up to $\sim 400 \mathrm{~km}$ inland. Other species that were captured well upstream of the estuary, albeit in small numbers, were the bull shark (Carchaminus lewas), freshwater sawfish (Pristis microdon), freshwater whipray (Himantura chaophraya), tarpon (Megalops cyprinoides) and greenback mullet (Liza subiridis).

Other species that were captured in the greater estuary of the Fitzroy River (i.e. King Sound), including Doctors Creek (Figure 1) are: the northern river shark (Glyphis sp. C), the milk shark (Rhizoprionodon acutus (Ruppell, 1837)), the winghead shark (Eusphyra blochii (Cuvier, 1816)), the dwarf sawfish (Pristis clavata), the lesser salmon catfish (Arius graeffei), shark mullet (Rhinomugil nasutus (De Vis, 1883)), king threadfin (Polydactylus macrochir (Güther, 1867)), scaly croaker (Nibea squamosa) and milk-spotted toadfish (Chelonodon patoca (Hamilton, 1822)). The northern river shark (Glyphis sp. C), which was captured in Doctors Creek, is extremely rare, and has not previously been recorded from Western Australia. It was previously known only from a few specimens collected in the Adelaide, East Alligator and South Alligator rivers in the Northern Territory and from the Fly River in Papua New Guinea (Taniuchi et al., 1991; Compagno and Niem, 1998; Thorburn et al., 2003; Museum and Art Galleries of the Northern Territory records).

\section{Spatial distribution of fish species in the Fitzroy River}

Localised fish communities in the Fitzroy River were shown to vary significantly $(p<0.001)$ between the upper, lower and middle reaches of the main channel/major tributaries (Table 3, Figure 1). These differences can largely be attributed to the higher occurrence of marine species in the lower and, to a lesser extent, middle reaches of the river, as well as to the disparity in species diversity between the lower (27 species), middle (22 species) and upper (17 species) reaches. Furthermore, ANOSIM suggested that the fish fauna associated with the smaller tributary sites and the upper Hann River gorge sites is significantly different to those in each of the lower, middle and upper riverine sites as well as the larger billabongs $(p<0.008)$. The gorge and sp.1. M. Ambassis sp.2 N. Glossamia aprion. O. Toxotes sp. P. Ammiataba percoides. Q. Hannia greenwayi. R. Hephaestus jenkinsi. S. Letopotherapon unicolor. T. Hypseleotris kmberleyensis. U. Mogurnda oligolepis. V. Oxyeleotris selhemim. W. Glossogobius ginris. Photographs: D. Morgan (A, F, I, N-Q, U) and M. Allen (B-E, G-H, J-M, R-S, $\mathrm{V}-(\mathrm{W})$. 


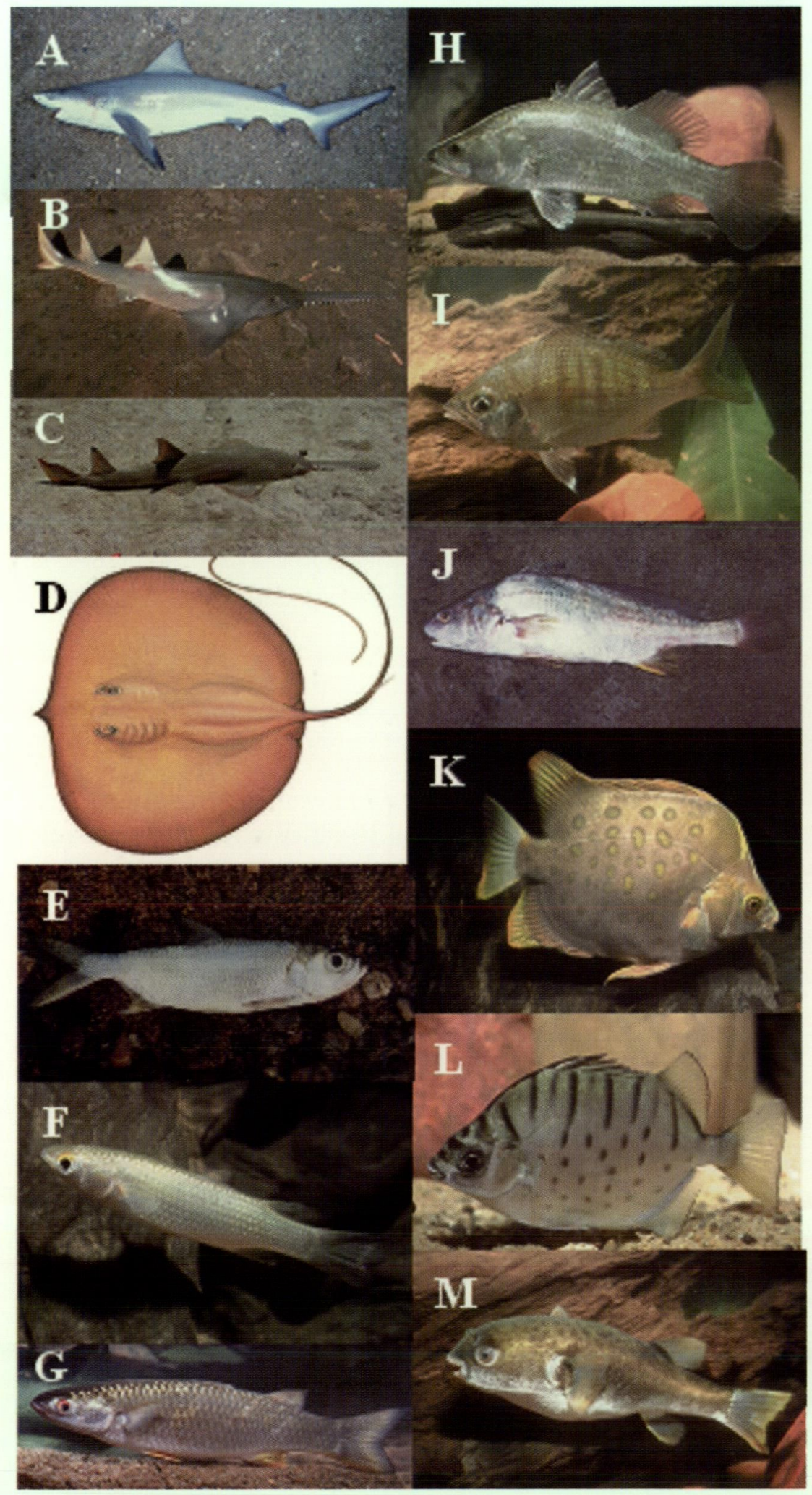

Plate 2 The marine/estuarine fish species found in the freshwaters of the Fitzroy River, Western Australia. A. Carcharinus leucas. B. Pristis microdon. C. Pristis clavata. D. Himantura chaophraya. E. Megalops cyprinoides. F. Liza subviridis. G. Liza alata. H. Lates calcarifer. I. Gerres filamentosus. J. Nibea squamosa. K. Scatophagus argus. L. Selenotoca multifasciata. M. Marilyna meraukensis. Not shown is Gerres subfasciatus. Photographs: D. Morgan (AB, E, G, J), M. Allen (F, H-I, K-M), D. Thorburn (C) and J. Ruse (D). 
Table 3 R-stat values for pairwise ANOSIM comparisons of the fish assemblages captured in the different regions/ habitats of the Fitzroy River. N.B. Significant faunal differences are represented by ${ }^{*} P<0.01$ and ${ }^{* *} P<0.001$. Global R $=0.343$.

\begin{tabular}{llllll}
\hline Region & LOWER & MIDDLE & UPPER & TRIBUTARY & BILLABONG \\
\hline MIDDLE & $0.326^{* *}$ & - & - & - & - \\
UPPER & $0.516^{* *}$ & $0.323^{* *}$ & - & - & - \\
TRIBUTARY & $0.393^{* *}$ & $0.408^{* *}$ & $0.355^{* *}$ & - & - \\
BILLABONG & $0.435^{* *}$ & 0.016 & $0.503^{*}$ & $0.284^{*}$ & - \\
GORGE & $0.781^{* *}$ & $0.531^{* *}$ & $0.551^{* *}$ & 0.011 & $0.572^{*}$ \\
\hline
\end{tabular}

tributary sites are generally dominated by smaller freshwater species, e.g. western rainbowfish $(M$. australis), spangled perch (L. unicolor), glassfish (Ambassis spp.), barred grunter (Anniataba percoides), bony bream ( $N$. erebi) (and also the rarer species in the gorges such as the Barnett River gudgeon ( $H$. kimberleyensis) and false-spotted gudgeon (Mogurnda oligolepis)), but lack the marine species and the lesser salmon catfish (A. graeffei). The larger billabongs were significantly different to all other major habitat sites with the exception of those in the middle river.

\section{Aboriginal names for the fish}

The Aboriginal names (for five languages) for the majority of fishes of the Fitzroy River are presented in Tables 4 and 5. The absence of a few names attests to either the rarity of some of the freshwater species (e.g. Barnett River gudgeon and Greenway's grunter) and the restriction of some of the marine/ estuarine species to the lower catchment (Nyikina land) (e.g. whipfin silver-biddy, roach, scaly croaker, spotted scat, striped butterfish and Merauke toadfish).

\section{DISCUSSION}

\section{Fish fauna of the Fitzroy River}

The importance of fish faunal surveys, particularly in northern Western Australia, is highlighted when considering the results of this study. For example, not only is the reporting of two undescribed species (i.e. Ambassis sp. 1 and Ambassis sp. 2) a major finding of this study, but the new records and range extensions of nine species in the west Kimberley attests to the necessity for such studies. The following range extensions were made during this project:

(1) Short-finned eels (A. bicolor) were not previously known from the Fitzroy River but have previously been found in the northern Pilbara and western Kimberley (Morgan et al., 2003, Western Australian Museum records).

(2) Black catfish ( $N$. ater) were not previously known from the Fitzroy River catchment, their only confirmed habitat in the Fitzroy River is at Dimond Gorge.

(3) False-spine catfish (N. pseudospinosus) in the Fitzroy River was previously only known from Manning Creek (Barnett River) (Allen and Feinberg, 1998) - now extended to include the Mary, Margaret and $\mathrm{O}^{\prime}$ Donnell rivers.

(4) Greenway's grunter ( $H$. greenwayi) was known only from the Hann and Isdell rivers, and has only been collected on two previous occasions (Allen and Allen, unpublished data; Rosen, Nelson and Butler in 1969 for the American Museum of Natural History) - now extended to include the Fitzroy, Margaret, Mary, Forest and Adcock rivers.

(5) False-spotted gudgeons (M. oligolepis) in the Fitzroy River were not previously known from the Adcock River (see Figure 1).

(6) Glyphis sp. C, which we captured in Doctor's Creek and is an undescribed speartooth shark that is listed as Endangered by Environment Australia, had not previously been recorded in Western Australia and is only known from. a few specimens captured in the Adelaide, East Alligator and South Alligator rivers in the Northern Territory and the Fly River in New Guinea (Taniuchi et al., 1991; Compagno and Niem, 1998; Thorburn et al., 2003; Museum and Art Galleries of the Northern Territory records).

(7) Dwarf sawfish ( $P$. clavata) was not known from the west Kimberley.

(8) Scaly croaker (N. squamosa) had not previously been recorded in the west Kimberley, although the Western Australian Museum records include a photograph from the northern Kimberley (Hutchins, pers. comm.) and Hutchins (2001) lists the species in the collections of the Western Australian Museum. Allen et al. (2002) describes the distribution of this species as being from the Victoria River (NT) east to the Norman River (QLD).

(9) Merauke toadfish (M. meraukensis) was not previously known to occur west of the Prince Regent River (Allen et al., 2002). 
Table 4 The Aboriginal names for the different freshwater fish species in the Fitzroy River.

\begin{tabular}{|c|c|c|c|c|c|c|}
\hline Freshwater species & Common name & Bunuba & Gooniyandi & Ngarinyin & Nyikina & Walmajarri \\
\hline Anguilla bicolor & Indian short-finned eel & Lanyi & - & - & - & - \\
\hline Nematalosa erebi & bony bream & Laarri & Laarri & Gunangurri & Bardijarr oobanyba & Lakarr \\
\hline Arius graeffei & lesser salmon catfish & Mulurra & Gooloomangarri & Moolirr & Barooloo & Kulamajarti \\
\hline Anodontiglanis dahli & toothless catfish & Waluna & Wirlingirri & Ganangad & - & - \\
\hline Neosilurus ater & black catfish & Manambu & - & - & Wardoo & Jungkali \\
\hline Neosilurus hyrtlii & Hyrtl's tandan & Junggali & Joonggali & Walaman & Wirlinyboo & Jungkali \\
\hline Neosilurus pseudospinosus & false-spine catfish & Manambu & - & - & Wardoo & Jungkali \\
\hline Porochilus rendahli & Rendahl's catfish & Junggali & Joonggali & Walaman & Wirlinyboo & Jungkali \\
\hline Strongylura krefftii & freshwater longtom & Langgarany & Langgaranyi & Biyira & Baloon & Langariny \\
\hline Melanotaenia australis & western rainbowfish & Walmarri & Walmadi & Gooljirimby & Dookool koodany & - \\
\hline Craterocephalus lentiginosus & Prince Regent hardyhead & Jinbirri & Thinbidi & - & Karlanyjarr & Jinpirr \\
\hline Ambassis sp. 1 & glassfish & Walmarri & Walmadi & Wolaman & Jilbirr & Jinpirr \\
\hline Ambassis sp. 2 & glassfish & Walmarri & Walmadi & Wolaman & Jilbirr & Jinpirr \\
\hline Glossamia aprion & mouth almighty & Thamali & Thamarli & Damari & Jarbarr & Parlkamarnu \\
\hline Toxotes sp. & Kimberley archerfish & Girrwali & Girrwali & Nalawarr & Marrbawool & Marrparl marrpal \\
\hline Amniataba percoides & barred grunter & Walarrabu & Jarlandi & Birlirndirr & Mook mook & Kalirrikalirri \\
\hline Hannia greenwayi & Greenway's grunter & - & - & Emana & - & - \\
\hline Hephaestus jenkinsi & black bream & Walngga & Jambinbaroo & Emana & Walnga & Jampinyparu \\
\hline Leiopotherapon unicolor & spangled perch & Bunda & Boornda & Wunggari & Jarrmoongka & Punta mangu \\
\hline Hypseleotris kimberleyensis & Barnett River gudgeon & - & - & - & - & - \\
\hline Mogurnda oligolepis & false-spotted gudgeon & Luthu & Loothoo & Nyagurlman & - & - \\
\hline Oxyeleotris selheimi & giant gudgeon & Nyaguna & Nyagoorna & Nyagurlman & Loojoo & - \\
\hline Glossogobius gituris & flathead goby & Nyaguna & - & Ngagulnun & Joolany & Luthu \\
\hline
\end{tabular}

Table 5 The Aboriginal names for the different marine/estuarine fish species in the Fitzroy River.

\begin{tabular}{|c|c|c|c|c|c|c|}
\hline Freshwater species & Common name & Bunuba & Gooniyandi & Ngarinyin & Nyikina & Walmajarri \\
\hline Carcharhinus leucas & bull shark & Ngan.gu & - & - & Ngawoonkoo & Ngangu \\
\hline Pristis microdon & freshwater sawfish & Galwanyi & Galwanyi & - & Wirridanyniny & Wirrdani \\
\hline Pristis clavata & dwarf sawfish & Galwanyi & Galwanyi & - & Wirridanyniny & Wirrdani \\
\hline Himantura chaophraya & freshwater whipray & Baya gawiy & - & - & Biya & Biya \\
\hline Megalops cyprinoides & Ox-eye herring, tarpon & - & Wayoo & - & Karlanyjarri & - \\
\hline Liza subviridis & greenback mullet & - & Goolgara & Bulurrngari & Lawoorrinyji & - \\
\hline Liza alata & diamond mullet & - & Goolgara & Bulurrngari & Lawoorrinyji & - \\
\hline Lates calcarifer & barramundi & Balga & Barlga & Deyo & Birloonkoordany & Murrulpal \\
\hline Gerres filamentosus & whipfin silver-biddy & - & - & - & - & - \\
\hline Gerres subfasciatus & roach & - & - & - & - & - \\
\hline Nibea squamosa & scaly croaker & - & - & - & - & - \\
\hline Scatophagus argus & spotted scat & - & - & - & - & - \\
\hline Selenotoca multifasciata & striped butterfish & - & - & - & - & - \\
\hline Marilyna meraukensis & Merauke toadfish & - & - & - & - & - \\
\hline
\end{tabular}


The 37 species of fish captured from the Fitzroy River during this study includes 23 freshwater species and 14 marine species that utilise the freshwaters. In addition to this, Allen and Leggett (1990) reported the strawman (Craterocephalus stramineus (Whitley, 1950) = Quirichthys stramineus) in the upper reaches of the Mary River $\left(18^{\circ} 42^{\prime} \mathrm{S}\right.$, $125^{\circ} 45^{\prime} \mathrm{E}$ ). Allen et al. (2002) list the seven-spot archerfish (Toxotes chatareus (Hamilton, 1922)) and Allen et al. (2002) and Doupé and Lenanton (1998) list the silver cobbler (Arius midgleyi Kailola and Pierce, 1988) from the Fitzroy River, however there are no specimens of these species in the WA Museum and it is unlikely that they are found in the Fitzroy River. The WA Museum however, has records of two other marine species from the lower non-tidal freshwaters of the river, i.e. giant herring (Elops hawaiensis Regan, 1909) and the anchovy (Thryssa aesturia (Ogilby, 1910)). Thus, the known species that are found in the non-tidal freshwaters of the Fitzroy River can be put at 40 species (24 freshwater and 16 marine/estuarine). This diversity is high by Western Australian standards, with the total number of freshwater species being marginally higher than that recorded for all rivers of the Pilbara (Indian Ocean Drainage Division, 12 species) and south-west (South-west Coast Drainage Division, 10 species) combined (Morgan et al., 1998, 2003; Allen et al., 2002). The Kimberley as a whole is diverse in terms of freshwater fish species, and this survey confirms the Fitzroy River as one of the most species-rich in the region. For example, surveys within the Kimberley by McKay (1971) listed 17 freshwater species from the Ord River, while Allen (1975) identified 18 freshwater species from the Prince Regent River and seven from the Roe River, Hutchins (1977) collected 19 freshwater species from each of Drysdale and Carson rivers (total $=24$ sp.) and Hutchins (1981) collected nine freshwater species from the Mitchell River. There is however, likely to be a similar number of freshwater species in the Ord River, with recent surveys by Doupé $e t$ al. (2003) capturing 19 species in Lake Kununurra and G. Allen and M. Allen (unpublished data) recording one other species in the lake in their total of 12 species. Allen et al. (2002) lists a further four freshwater species for the Ord River, taking the known total to 24 species. Within the Northern Territory Pollard (1974) collected 28 freshwater fishes from the East Alligator River and also identified a further 15 predominantly marine species, the majority of which were also captured in the Fitzroy River. Pollard (1974) also included the Aboriginal (Oenpelli) names for many of the species. Bishop et al. (2001) listed 37 freshwater fishes from the Alligator Rivers (East and South).

Approximately two-thirds of Australia's 200 freshwater fish species occur within northern Australia and within the Kimberley there are approximate 50 species of which 18 are endemic (Allen and Leggett, 1990; Allen et al., 2002). The high endemicity of the Kimberley is probably a consequence of the rugged topography and diverse habitats that have acted as isolating mechanisms and have thus enhanced speciation (Allen and Leggett, 1990; Pusey et al., 1995). The high diversity of the Fitzroy River may be both a factor of the large catchment size (e.g. Pusey and Kernard (1996) demonstrated a positive relationship between species richness and catchment area in North Queensland) and the high degree of variable habitats, particularly when comparing the main channel, billabongs and creek systems of the floodplain to the high relief gorge country of the headwaters. The topography of the upper Hann River appears to have had a major influence in governing the evolution of at least a few species, e.g. Barnett River gudgeon (H. kimberleyensis) and Greenway's grunter (H. greenwayi). Freshwater fishes endemic to the Fitzroy River include: $H$. kimberleyensis, $H$. greenwayi (also found in the Isdell River (Allen and Allen, unpublished data)) and possibly the two undescribed glassfishes (Ambassis sp. 1 and sp. 2) and archerfish (Toxotes sp.). The absence of a number of species that are endemic to nearby, more northern Kimberley rivers, e.g. five species of Terapontidae (Hephaestus epirrhinos Vari and Hutchins, 1978, Leiopotherapon macrolepis Vari, 1978, Syncomistes kimberleyensis Vari, 1978, Syncomistes rastellus Vari and Hutchins, 1978 and Syncomistes trigonicus Vari, 1978), four eleotrids (Hypseleotris ejuncida Hoese and Allen, 1983, Hypseleotris regalis Hoese and Allen, 1983, Kimberleyeleotris hutchinsi Hoese and Allen, 1987 and Kimberleyeleotris notata Hoese and Allen, 1987), one Atherinidae (Craterocephalus helenae Ivantsoff, Crowley and Allen, 1987) and two species of the Melanotaeniidae (Melanotaenia gracilis Allen, 1978 and Melanotaenia pygmaea Allen, 1974), suggests that these species have evolved in these remote, more northern rivers of the Kimberley and that there has been no recent connection between these rivers and the Fitzroy River.

The notable change is fish faunal assemblages throughout the Fitzroy River is highlighted by the fact that there are significant differences in the fish fauna found in the lower, middle and upper main channel and major tributary sites of the Fitzroy River as well as between these sites and the smaller less permanent tributaries on the floodplain and in the upper Hann River. Within the Fitzroy River there is a notable increase in species richness in the lower reaches of the river compared to the headwater streams. For example, 27 species were captured in the lower reaches, 22 in the middle and 17 in the upper reaches of the main channel and major tributaries, while the smaller tributary and upper Hann River sites contained 18 and 13 species, 
respectively, and 19 species were captured from the major billabongs of the river.

\section{Aboriginal values of the Fitzroy River}

The Bunuba, Gooniyandi, Ngarinyin, Nyikina and Walmajarri people have strong economic, cultural and religious affiliations with the fish, the river and fishing. Fishing is an integral part of life for both Aboriginal and non-Aboriginal people of the Fitzroy River catchment, which is not surprising considering that throughout most of its length large numbers of important food species, e.g. black bream ( $H$. jenkinsi), barramundi ( $L$. calcarifer) and lesser salmon catfish (A. graeffei) are readily captured. The utilisation of live and fresh bait has also led to a good understanding of the smaller species in the river.

Not only are the river, its tributaries, billabongs and large and small pools important for food, but they are extremely valuable from a cultural perspective. For example, many of the sites sampled during this survey, particularly permanent deep pools in gorges and billabongs, are known as 'Living Waters'. They are home to Creator 'snakes' that must be treated with ritual and respect to maintain water flows, renew aquatic life and ensure human welfare. The floodplain environment and riparian zone of the Fitzroy River valley is also important for hunting. Stock on pastoral leases readily accesses the river along most of its length.

The Kimberley Land Council and the Kimberley Language Resource Centre have a wealth of information regarding many aspects of the cultural beliefs and languages of the people of the Fitzroy River. A great deal of language was recorded during these field trips by the KLRC.

\section{Impacts of a dam on the Fitzroy River}

While providing water for agriculture and domestic uses, the proposed dam sites in the Fitzroy River have also been seen as a means of controlling natural flooding in the Fitzroy River, thereby allowing intensive agriculture to be developed as in the case of the lower Ord River (Anon, 1993). A dam would create altered flow regimes and changes in seasonal distributions of flow downstream of the dam and there are uncertainties in relation to the river's hydrology relating to sediment loads, impacts of reduced flows and changes in downstream water quality (Ruprecht and Rodgers, 1998). The reduction in peak flow volumes if either Dimond Gorge or Margaret Gorge were dammed would be about one-third (Anon, 1993). However, while flow would be reduced during the wet, during the dry it would be increased to provide for downstream irrigation (Anon, 1993). The altered flow regimes of the river will inevitably cause a change in the prevailing fish fauna immediately above the dam, but will also impact the distribution of fish below the dam. Thus migratory species such as barramundi, the endangered freshwater sawfish, ox-eye herring and mullets will no longer have access to habitat above dam sites, but the altered flow regimes and flood levels will also impact the recruitment of other species. The Fitzroy River acts as a nursery for many of these species and in the case of the freshwater sawfish, the river is currently the most important known refuge for the species (see Thorburn et al. 2003). Migratory species such as those listed above have been excluded from the Ord River above Lake Kununurra as a result of the diversion dam (Doupé et al., 2003). During the wet season the floodplain environment of the lower Fitzroy is important not only as spawning grounds for many of the river's fishes, but is also likely to act as a nursery ground for many of these species. Any reduction in flooding may therefore inhibit larval recruitment into the adult populations of some species. Furthermore, dams generally favour species that prefer lentic waters over those more conducive to lotic habitats and ultimately alter fish community structure (e.g. Morgan et al., 2002).

One of the proposed dam sites, Dimond Gorge, had the second highest number of species recorded (17) and was the only location where the black catfish (N. ater) was collected. Barramundi and the endangered freshwater sawfish are known to migrate at least as far upstream as these sites.

\section{Grazing}

Williams and Pen (1998) noted that much of the upper Fitzroy River catchment shows considerable signs of degradation through heavy grazing, with many large denuded and eroding areas. Much of the riparian zone shows signs of degradation from livestock, while many of the wetlands and billabongs become nutrient enriched and trampled by congregations of cattle during the dry. The trampling of small pools by cattle may impact on benthic species such as the gobies, gudgeons and plotosid catfishes, although further work is required to ascertain any impacts. As a precautionary measure, areas of important fish habitat should be identified and fenced from cattle, e.g. Lake Skeleton (site 10).

\section{Conclusions}

The species richness and uniqueness of the fish fauna of the Fitzroy River, its importance to the people of the west Kimberley for food and recreation, and the diverse significance of the river as a 'living cultural landscape' to Aboriginal people of the region (including the Bunuba, Gooniyandi, Ngarinyin, Nyikina and Walmajarri) makes it one of Australia's great river systems. The Fitzroy River and its estuary, which provides refuge for a number of rare and little known species (e.g. the endangered 
freshwater sawfish, Greenway's grunter, Barnett River gudgeon, false-spotted gudgeon and three undescribed species), warrants careful consideration before any proposed land use changes are implemented.

\section{ACKNOWLEDGEMENTS}

This project would not have been possible without either the financial support of the Natural Heritage Trust, the Kimberley Land Council (KLC), the Kimberley Language Resource Centre (KLRC) and Murdoch University or the large amount of community involvement that was generated by the KLC and the KLRC. Thanks particularly to Ismahl Croft for his great organisational skills during the project. Thanks to Tasmin Wagner, Gracie Mulligan, Emily Knight and the many others for their involvement in the Aboriginal names for the fish. The community involvement was tremendous and while it is not possible to thank everyone individually, we would like to thank the people of the West Kimberley for their great support. Thanks also to Mary Aiken, Gerry Allen, Australian Nature Conservancy, Leslie Baxter, Tom Baxter, Ferdy Bergmann, Big Barra's One Stop Shop (Derby), CALM (Fitzroy Crossing), Neil Buckle, Doreen Button, Dean Campbell-Smith, Martin Chestnut, Bevan Corbert, June Davis, Karen Dayman, Joe Duncan, Fisheries WA (Broome), Josephine Forrest, Ethel Forrest, Wendy Forrest, Christine Forrest, Nelson Forrest, Howard Gill, Ari Gorring, Steven -Head, Malachy Hobbs, Neil \& Gwen Hogstrom, Barry Hutchins, Ronnie Jimbidee, George Jubadah, Jim \& Geraldine Kelly, Mable King, Emily Knight, Helen Larson, Kim McKay, Scotty Martin, Julie Melbourne, Mangkaja Arts (Fitzroy Crossing), Rosie Mulligan, Gracie Mulligan, Bessie Nargoodah, Pansy Nulgit, Mona Oscar, Marilyn Oscar, David Pate, Edgar Price, Wibiy Nancy Rogers, Andrew Rowland, John Savage, Mervyn Street, Dicky Tataya, Nugget Tataya, Claire Thirkell, Michael Thirkell, Anna Thirkell, Meegan Thirkell, Dean Thorburn, Kevin Tromp, Tom Vigilante, Simon Visser, Tamsin Wagner, Lucy Walgarrie, Lynette Wangandin, Jeanie Warbie, Yvonne White, Trevor Williams and Patricia Yadda.

\section{REFERENCES}

Allen, G.R. (1975). A preliminary checklist of the freshwater fishes of the Prince Regent River Reserve north-west Kimberley, Western Australia. In, Miles, J.M. and Burbidge, A.A. (eds), A biological survey of the Prince Regent River Reserve North-west Kimberley, Western Australia in August, 1974. Wildlife Research Bulletin of Western Australia 3: 1-116.

Allen, G.R. and Leggett, R. (1990). A collection of freshwater fishes from the Kimberley region of
Western Australia. Records of the Western Australian Museum 14: 527-545.

Allen, G.R., Midgley, S.H. and Allen, M. (2002). Field guide to the freshwater fishes of Australia. Western Australia Museum, Perth.

Anon. (1993). Fitzroy Valley irrigation a conceptual study. For the Kimberley Resources Development Office. Prepared by ACIL Economics and Policy Pty Ltd, Kinhill Engineers Pty Ltd, Bryn Roberts and Associates and Water Authority of Western Australia.

Bishop, K.A., Allen, S.A., Pollard, D.A. and Cook, M.G. (2001). Ecological studies on the freshwater fishes of the Alligator Rivers region, Northern Territory: Autecology. Supervising Scientist Report 145, Supervising Scientist, Darwin.

Clarke, K.R and Gorley, R.N. (2001). PRIMER v5: User manual/tutorial. Plymouth: PRIMER-E.

Compagno, L.J.V. and Niem, V.H. (1998). Carcharhinidae requiem sharks. pp. 1312-1360. In, Carpenter, K.E. and Niem, V.H. (eds), The living marine resources of the western central Pacific, Volume 2 Cephalopods, crustaceans, holothurians and sharks. Food and Agriculture Organisation of the United Nations, Rome.

Doupé, R. and Lenanton, R. J. (1998). Fishes of the Fitzroy River: diversity, life history and the effects of river regulation. In, Storey, A. and Beesley, L. (eds), Limnology of the Fitzroy River, Western Australia: a technical workshop. Proceedings of a workshop held on $18^{\text {th }}$ February 1998, at Edith Cowan University, Claremont Campus, Claremont, Western Australia.

Doupé, R., Morgan, D., Gill, H., Rowland, A and Annandale, D. (2003). Ecological and social issues concerning the establishment of a recreational barramundi fishery in Lake Kununurra. Report to the Lake Kununurra Fish Stock Enhancement Committee \& Ord Land and Water Inc.

Goh, J. (1998). The Fitzroy River catchment: hydrology and flood characteristics. In, Storey, A. and Beesley, L. (eds), Limnology of the Fitzroy River, Western Australia: a technical workshop. Proceedings of a workshop held on $18^{\text {th }}$ February 1998, at Edith Cowan University, Claremont Campus, Claremont, Western Australia.

Hutchins, J.B. (1977). The freshwater fish fauna of the Drysdale River National Park North Kimberley, Western Australia. In, Kabay, E.D. and Burbidge, A.A. (eds), A biological survey of the Drysdale River National Park North Kimberley, Western Australia in August, 1975. Wildlife Research Bulletin of Western Australia 6: 1-133.

Hutchins, J.B. (1981). Freshwater fish fauna of the Mitchell Plateau Area, Kimberley, Western Australia. In, Biological survey of Mitchell Plateau and Admiralty Gulf, Kimberley, Western Australia. Western Australian Museum, Perth.

Hutchins, J.B. (2001). Checklist of the fishes of Western Australia. Records of the Western Australian Museum Supplement No. 63: 9-50.

Mapinfo Corporation (1998). Mapinfo professional- user's guide. Mapinfo Corporation, New York.

McKay, R.J. (1971). Fish. In, Kitchener, D.J. (ed.), Preliminary report of a biological survey of the Ord River 
basin, pp. 1-8. Unpublished mimeograph report. Western Australian Museum, Perth.

Morgan, D.L., Gill, H.S. and Potter, I.C. (1998). Distribution, identification and biology of freshwater fishes in south-western Australia. Records of the Western Australian Museum Supplement 56: 1-97.

Morgan, D., Gill, H., Allen, M. and Maddern, M. (2003). Distribution and biology of fish in inland waters of the Pilbara (Indian Ocean) Drainage Division. Report to the Natural Heritage Trust. March 2003. Project Number 003026.

Morgan, D.L., Hambleton, S.J., Gill, H.S. and Beatty, S.J. (2002). Distribution, biology and likely impacts of the introduced redfin perch (Perca fluviatilis) (Percidae) in Western Australia. Marine and Freshwater Research 53: 1211-1221.

Nelson, J.S. (1994). Fishes of the world. John Wiley and Sons, New York.

Pollard, D.A. (1974). The freshwater fishes of the Alligator Rivers 'Uranium Province' area (top end, Northern Territory), with particular reference to the Magela Creek catchment (East Alligator River system). Australian Atomic Energy Commission Report AAEC/E305.

Pusey, B.J., Arthington, A.H. and Read, M.G. (1995). Species and spatial variation in fish assemblage structure in two rivers of the Wet Tropics of northern Queensland, Australia. Environmental Biology of Fishes 42: 181-199.

Pusey, B.J. and Kernard, M.J. (1996). Species richness and geographical variation in assemblage structure of the freshwater fish fauna of the Wet Tropics region of northern Queensland. Marine and Freshwater Research 47: 563-573.
Ruprecht, J. and Rogers, S. (1998). Hydrology of the Fitzroy River. In, Storey, A. and Beesley, L. (eds), Limnology of the Fitzroy River, Western Australia: a technical workshop. Proceedings of a workshop held on $18^{\text {th }}$ February 1998, at Edith Cowan University, Claremont Campus, Claremont, Western Australia.

Thorburn, D.C., Peverell, S., Stevens, J.D., Last, P.R. and Rowland, A.J. (2003). Status of freshwater and estuarine elasmobranches in northern Australia. Report to the Natural Heritage Trust.

Storey, A. (1998). Irrigated agriculture on the Fitzroy River: background and aims of the workshop. In, Storey, A. and Beesley, L. (eds), Limnology of the Fitzroy River, Western Australia: a technical workshop. Proceedings of a workshop held on $18^{\text {th }}$ February 1998, at Edith Cowan University, Claremont Campus, Claremont, Western Australia.

Taniuchi, T., Shimizu, M., Sano, M., Baba, O. and Last, P.R. (1991). Description of freshwater elasmobranches collected from three rivers in northern Australia. University Museum, University of Tokyo, Nature and Culture 3: 11-26.

Williams, P. and Pen, L. (1998). Wild rivers of the Kimberley region. In, Storey, A. and Beesley, L. (eds), Limnology of the Fitzroy River, Western Australia: a technical workshop. Proceedings of a workshop held on $18^{\text {th }}$ February 1998, at Edith Cowan University, Claremont Campus, Claremont, Western Australia.

Manuscript received 14 October 2003; accepted 12 November 2003 
Appendix 1 The sites sampled in the Fitzroy River catchment.

\begin{tabular}{|c|c|c|c|}
\hline $\begin{array}{l}\text { Site } \\
\text { Number }\end{array}$ & $\begin{array}{l}\text { Site } \\
\text { Locality }\end{array}$ & $\begin{array}{l}\text { Site } \\
\text { Number }\end{array}$ & $\begin{array}{l}\text { Site } \\
\text { Locality }\end{array}$ \\
\hline 1 & Fitzroy River - Myroodah Crossing & 34 & Udialla Station - Fitzroy River \\
\hline 2 & Minnie River & 35 & Leopold Station - Little Spring \\
\hline 3 & Fitzroy River $\sim 5 \mathrm{~km}$ downstream of Udialla & 36 & Mary River - Yiyili Community \\
\hline & Station & 37 & Margaret River, Me No Savy \\
\hline 4 & $\begin{array}{l}\text { Tributary Fitzroy River } \sim 10 \mathrm{~km} \text { upstream } \\
\text { Udialla Station }\end{array}$ & $\begin{array}{l}38 \\
39\end{array}$ & $\begin{array}{l}\text { Margaret River, Joorda Doognhingi } \\
\text { Margaret River, Nyalingi }\end{array}$ \\
\hline 5 & Fitzroy River - upstream Udialla Station & 40 & Margaret River, Lambardi \\
\hline 6 & Manguel Creek & 41 & O'Donnell River / Margaret River junction, \\
\hline 7 & Lake Alma & & Balmoonggoo \\
\hline 8 & Geegully Creek & 42 & Gorge near Margaret River, Girramoo \\
\hline 9 & Fitzroy River - opposite Minnie River mouth & 43 & Margaret River \\
\hline $\begin{array}{l}10 \\
11\end{array}$ & $\begin{array}{l}\text { Lake Skeleton } \\
\text { Lake on Old Great Northern Hwy }\end{array}$ & 44 & $\begin{array}{l}\text { Fitzroy River - Cadjeput - Old Mornington } \\
\text { Station }\end{array}$ \\
\hline 12 & $\begin{array}{l}\text { Lake on Great Northern Hwy } \sim 131 \mathrm{~km} \text { wets } \\
\text { Fitzroy Crossing }\end{array}$ & $\begin{array}{l}45 \\
46\end{array}$ & $\begin{array}{l}\text { Fitzroy River - Dimond Gorge } \\
\text { Tributary of Dimond Gorge }\end{array}$ \\
\hline 13 & Mt Wynne Creek - Great Northern Hwy & 47 & Small billabong - tributary of Dimond Gorge \\
\hline 14 & Mt Hardman Creek - Great Northern Hwy & 48 & Anna Creek - Old Mornington Station \\
\hline 15 & $\begin{array}{l}\text { Brooking Channel, Baralwani - Great Northern } \\
\text { Hwy }\end{array}$ & $\begin{array}{l}49 \\
50\end{array}$ & $\begin{array}{l}\text { Anna Creek - Old Mornington Station } \\
\text { Adcock River - Old Mornington Station }\end{array}$ \\
\hline 16 & Old Crossing - Fitzroy River & 51 & Tributary of Adcock River \\
\hline 17 & Brooking Creek - Geikie Gorge Rd & 52 & Grave Creek - Adcock River \\
\hline 18 & $\begin{array}{l}\text { Fitzroy River, Sheep Camp, Wuruiya - Geikie } \\
\text { Gorge }\end{array}$ & 53 & Manning Creek Gorge \\
\hline 19 & Crocodile Creek - Geikie Gorge & 54 & $\begin{array}{l}\text { Lower Fitzroy River - Small tributary of } \\
\text { Willuns Pool }\end{array}$ \\
\hline 20 & Wirangarra $20 \mathrm{~km}$ south Fitzroy Crossing & 55 & Duck Hole Creek - Goray \\
\hline 21 & $\begin{array}{l}\text { Billabong near Wirangarra - small lake near } \\
\text { Ngurtawarta community }\end{array}$ & $\begin{array}{l}56 \\
57\end{array}$ & $\begin{array}{l}\text { Duck Hole Billabong } \\
\text { Fitzroy River - Cherabin Camp }\end{array}$ \\
\hline 22 & Dawuwarriya - near Ngurtawarta Community & 58 & Cherabin Creek - Crocodile Dam (stock dam) \\
\hline 23 & Creek crossing - Geikie Gorge Rd & 59 & Booline Creek \\
\hline 24 & Gurangajar Creek - Geikie Gorge Rd & 60 & Hann River, Barlmundurra - Gibb River Rd \\
\hline 25 & Two Mile Creek, Barangarri & 61 & Hann River Gorge \\
\hline 26 & $\begin{array}{l}\text { Goarrii } \sim 10 \mathrm{~km} \text { E Fitzroy Crossing off Great } \\
\text { Northern Hwy }\end{array}$ & $\begin{array}{l}62 \\
63\end{array}$ & $\begin{array}{l}\text { Hann River - Bella Yards } \\
\text { Srake Creek - Hann River }\end{array}$ \\
\hline 27 & Bluebush Creek 15km E Fitzroy Crossing & 64 & Snake Creek, Bijili - Hann River \\
\hline 28 & $\begin{array}{l}\text { Margaret River (Mayalnga) - crossing near } \\
\text { Muludja Community }\end{array}$ & 65 & $\begin{array}{l}\text { Barnett River - downstream of Barnett River } \\
\text { Gorge }\end{array}$ \\
\hline 29 & Jiliyardi (billabong near Bayulu community) & 66 & Adcock River Gorge \\
\hline 30 & Mimbi Cave (Mt Pierre Station) & 67 & Forest River - Jubilee Downs \\
\hline 31 & $\begin{array}{l}\text { Christmas Creek - Bohemia Downs Sation, } \\
\text { Kupartiya Community) }\end{array}$ & $\begin{array}{l}68 \\
69\end{array}$ & $\begin{array}{l}\text { Snake Creek - Camballin } \\
\text { Telegraph Pool - Fitzroy River }\end{array}$ \\
\hline 32 & Fitzroy River - Willare Bridge & 70 & Camballin - Fitzroy River \\
\hline 33 & Udialla Station - spring near Oyster Patch & & \\
\hline
\end{tabular}

